УДК 342.98:35 (477)

DOI https://doi.org/10.32837/pyuv.v2i3(28).360

\author{
Л. М. Корнута \\ кандидат юридичних наук, доцент, \\ доиент кафедри адміністративного і фінансового права \\ Національного університету «Одеська юридична академія»
}

\title{
ПРАКСЕОЛОГІЧНИЙ ПІДХІД ЯК ОСНОВА ЕФЕКТИВНОГО ЗАБЕЗПЕЧЕННЯ ПІДВИЩЕННЯ КВАЛІФІКАЦІЇ ДЕРЖАВНИХ СЛУЖБОВЦІВ В УКРАЇНІ
}

Стрімкий розвиток державотворення, управлінських процесів та інформаційних комунікацій породжує принципово нові підходи до інституту державної служби та місця в них професійних службовців, що здатні ефективно та своєчасно реагувати на такі активні зміни, а також, володіючи високими професійними якостями, можуть втілювати їх в життя. Окрім того, інтеграційні світові процеси зумовлюють пошук ефективних шляхів вдосконалення національних освітніх систем підготовки державних службовців, підвищення якості їх професійної освіти, модернізації самого змісту підготовки, а також модернізації підходів та видів професійної освіти державних службовців. Одним із важливих чинників удосконалення процесу підготовки майбутніх професійних кадрів є питання оптимізації підготовки державних службовців до ефективного виконання професійних повноважень. Основою такої підготовки є з'ясування оптимальних видів підготовки державних службовців та механізмів навчання, а також формування у державних службовців готовності до виконання професійних повноважень, що передбачає праксеологічний складник та базується на праксеологічному підході у процесі професійної підготовки держслужбовців.

На підставі аналізу спеціалізованої літератури можна констатувати, що праксеологічний підхід активно розвивався в економічній сфері та менеджменті. Однак з огляду на особливості реформування підходів до професійної освіти, особливо на питання підвищення кваліфікації державних службовців, можна стверджувати про можливість застосування праксеологічного підходу в сфері державної служби. Так, уже сьогодні польські дослідники в галузі вищої освіти (Т. Kotarbi ski, W. Strykowski, J. Strykowska) наголошують на важливості формування праксеологічних компетенцій у процесі підготовки майбутніх управлінців до ефективної професійної діяльності та кваліфікованого підходу до вирішення відповідних завдань. Водночас, попри широке коло досліджень, невирішним залишаться питання реалізації праксеологічного підходу у забезпеченні якості професійної підготовки спеціалістів.

Питання професійної освіти та професійної підготовки державного службовця тією чи іншою мірою розглядали у своїх працях Г. Атаманчук, Л. Біла-Тіунова, Ю. Битяк, С. Ващенко, Н. Грицяк, С.Д. Дубенко, С. Ківалов, Т. Коломоєць, В. Луговий, П. Лютіков, В. Малиновський, А. Мудрик, Р. Науменко, Т. Недашківська, Н. Нижник, О. Оболенський, В. Олуйко, Я. Радиш та інші. Водночас, попри широке коло досліджень, невирішеним залишаться питання реалізації праксеологічного підходу у забезпеченні якості професійної підготовки державних службовців, тому подальший розвиток законодавства 3 питань державної служби і адаптація інституту державної служби до стандартів Європейського Союзу зумовлюють актуальність обраної теми дослідження.

Метою статті є з'ясування сутності праксеологічного підходу як основи підвищення кваліфікації державних службовців та окреслення можливостей його застосування у системі професійної підготовки держслужбовців України в контексті забезпечення її якості.

Стрімкі євроінтеграційні процеси, що відбуваються в Україні, висувають нові вимоги до сучасного державного службовця як організатора реалізації державної служби та фахівця, здатного на високому професійному рівні виконувати повноваження, вирішувати складні управлінські завдання, конструктивно взаємодіяти на усіх рівнях управління та відповідати професійним викликам сьогодення. 3 огляду на це важливого значення набуває якість професійної підготовки державних службовців та з'ясування найбільш необхідних та ефективних видів такої підготовки. Сьогодення вимагає системної і комплексної підготовки державних службовців з новим активно-творчим стилем мислення (політичним, правовим, економічним, соціальним, психолого-педагогічним та управлінським). Можливість забезпечення потрібного рівня професіоналізму державних службовців реалізується шляхом підвищення їх кваліфікації. Наявна система професійного навчання українських державних службовців продовжує забезпечувати гідний рівень освіти на академічному рівні але, на жаль, повільно реалізовує заходи щодо систематичного аналізу потреб у підвищенні кваліфікації персоналу та практичного підходу до набуття необхідних компетентностей. Так, принципи професійного навчання державних службовців, такі 
як професійне зростання особистості, андрагогіка, інноваційність, неперервність, диференціація, ефективність, акмеологічність та синергетичність, частково враховуються під час оновлення змісту навчання державних службовців.

3 огляду на виокремлення у системі професійної підготовки державних службовців трьох складників - змістового, технологічного й особистісного - у контексті дослідження необхідно акцентувати увагу на технологічному складнику як такому, що забезпечує реалізацію праксеологічного підходу [3]. Саме праксеологічний складник підготовки державного службовця являє собою найважливішу змістову характеристику професійної спрямованості особистості майбутнього професіонала [6, с. 33].

Головне завдання праксеологічного підходу у процесі підготовки державних службовців полягає у вивченні й упровадженні необхідних знань для здійснення ефективної професійної діяльності, а також цінностей і змісту, цілей, професійних завдань та відповідних результатів. Досить слушно зауважує Н. Сацков, що реалізація праксеологічного підходу грунтується на інтеграції знання і діяльності як специфічної форми активного ставлення до поставлених завдань [7, с. 203]. Дві величини - знання й ефективна діяльність - $€$ основою праксеологічного підходу як цілеспрямованої системи принципів, що визначають загальну мету та стратегію орієнтованих праксеологічних дій і показують, як знання перетворюються на безпосередні професійні навички та уміння.

Використання праксеології у сфері професійної підготовки державних службовців створить основу для розуміння та дослідження професійної службової діяльності 3 позиції практичних цінностей, зокрема ефективності та результативності. Це важливо в процесі оцінювання результатів службової діяльності. Польський науковець T. Kotarbiński окреслив праксеологію як загальну теорію організації діяльності в контексті її ефективності й оптимізації, визначив та описав правила ефективної роботи та перерахував переваги. Саме ефективність виступає як показник якості професійного навчання, а також як якісна категорія, що сприяє розвитку та вдосконаленню професійної діяльності державних службовців [8, с. 113].

Водночас ефективність діяльності системи професійного навчання державних службовців може бути досягнута за умови відповідності професійної підготовки та післядипломної освіти до вимог освіти для суспільства, побудованого на знаннях і інформації. Цими вимогами є такі: освіта протягом усього життя; освіта без кордонів, що грунтується на інформаційно-комп'ютерних технологіях і доповнює традиційні методи і технології новими можливостями; освіта за креативними моделями навчання та індивідуальними освітніми траєкто- ріями; освіта, що розвивається на основі фундаментальних знань. Одним із видів професійного навчання, що покликаний забезпечити високу освіченість та професійну компетентність державних службовців, є саме підвищення кваліфікації.

Результати багаторічних наукових пошуків вітчизняних і зарубіжних науковців і фахівців щодо визначення поняття «підвищення кваліфікації» були використані для підготовки документа «Положення про систему професійного навчання державних службовців, голів місцевих державних адміністрацій, їх перших заступників та заступників, посадових осіб місцевого самоврядування та депутатів місцевих рад" [2]. У цьому нормативному акті дається визначення усіх складників системи професійного навчання державних службовців, зокрема підготовки, перепідготовки та підвищення кваліфікації.

Варто пам'ятати, що проблему підвищення кваліфікації державних службовців можна розглядати й у межах безперервної освіти. Праксеологічний підхід таке дозволяє. Так, більшість розвинених держав здійснює політику безперервного продовження освіти й підготовки кадрів. Наприклад, у Франції закон вимагає, щоб кожна організація, кількість службовців у якій перевищує 10 осіб, витрачала не менше ніж 0,5\% загальної суми заробітної плати на навчання, що здійснюється вперше, і 1,1\% - на продовжене навчання [5, с. 342]. Водночас термін «підвищення кваліфікації» у світовій і вітчизняній практиці найчастіше тлумачиться як підтримуюче й додаткове професійне навчання за фаховим спрямуванням без зміни рівня попередньо здобутої за певним фахом кваліфікації. Коректність визначення цього терміна є обґрунтованою у тому сенсі, що кваліфікація фахівця повинна підвищуватись, а рівень цієї кваліфікації- ні. Більш виправданим для вживання в зазначеному аспекті, можна стверджувати, був би термін «підтримуюча освіта», або «підтримуюче навчання». Окрім того, з'ясувавши сутність поняття «підвищення кваліфікації», вважаємо, що важливо встановити, чим вона є для державних службовців - правом чи обов'язком.

Що стосується обов'язку державних службовців підвищувати свою кваліфікацію, то слід керуватися тим, що вони займають у державних органах відповідні посади. Посада є частиною організаційної структури державного органу, тому правовий статус є узгодженим і взаємопов'язаним із правовим статусом інших посад у цьому органі. До осіб, що претендують на заміщення цих посад, висуваються вимоги як загального, так і спеціального характеру, що залежать від рівня підготовки й кваліфікації. Під час функціонування державних органів постійно змінюються, ускладнюються й удосконалюються форми й методи публічного управління. Це відображається в суспільних від- 
носинах, що регулюються. Це диктує необхідність постійного підвищення кваліфікаційних вимог до тієї чи іншої посади порівняно з тими, що були на час призначення особи на цю посаду.

Зміни кваліфікаційних вимог за посадою - це закономірне явище, об'єктивно зумовлене сучасними реаліями реформування в державі. 3 огляду на це аналіз принципу відповідності кваліфікації державного службовця до його посади залишається незмінним. Щоб відповідати займаній посаді й успішно виконувати покладені на службовця обов'язки, він повинен постійно підвищувати свою кваліфікацію. Це стає однією з умов для заміщення посади й подальшого виконання професійних обов'язків. Окрім цього, Закон України «Про державну службу» встановив, що основним обов' язком державного службовця є постійне удосконалення організації своєї роботи й підвищення професійної кваліфікації [1].

Різні підходи до категорії підвищення кваліфікації державних службовців відзначаються і в правових актах інших країн. Так, в Законі Республіки Білорусь «Про основи служби в державному апараті» зазначено, що для державних службовців створюються належні умови для перепідготовки й підвищення кваліфікації, що включають за необхідності отримання в установленому порядку другої вищої або іншої спеціальної освіти у відповідних навчальних закладах, а також стажування й самоосвіту. Результати перепідготовки й підвищення кваліфікації є однією з підстав для службового просування державного службовця [4].

у Німеччині розрізняють кілька видів підвищення кваліфікації. Службове підвищення кваліфікації в законодавстві визначається завданням як окремого співробітника, так і адміністрації, але не є примусовою вимогою. Співробітник зобов'язаний брати участь у заходах з підвищення кваліфікації або у рівнозначній діяльності. Це сприяє покращенню виконання посадових обов'язків. Він повинен також бути в курсі вимог у межах свого кар'єрного рівня настільки, наскільки це служить його пристосуванню до підвищених i змінених професійних вимог. Відповідно до цього адміністрація зобов'язана загалом сприяти підвищенню кваліфікації, що має на меті розвиток здібностей для зайняття вищих посад.

Специфіка функціонування системи підвищення кваліфікації державних службовців у контексті праксеологічного підходу полягає в тому, що вона є підсистемою державної служби, обслуговує її, готуючи високопрофесійні кадри. Це відбувається через вирішення низки таких завдань: приведення рівня професійних знань, умінь і навичок державних службовців у відповідність до вимог теорії та практики публічного управління; вивчення й застосування на практиці передового світового досвіду й досягнень науки державного будівництва та науки управління; формулюван- ня установок на оволодіння предметом діяльності у сфері державної служби; формування професійних здібностей державних службовців.

Підвищення кваліфікації державних службовців як важливий складник професійної освіти на державній службі розглядається одночасно як обов'язок і право керівника органу й державного службовця. У гармонійному поєднанні цих двох складових частин полягає успіх діяльності державних органів і працівників. Тобто проходження навчання у певних організаційно-правових формах є не тільки правом, але і обов'язком державних службовців. Обов'язком державних органів має бути планування, організація і контроль за їх навчанням, а правом - можливість вимагати від державних службовців проходження запланованого навчання.

Отже, розглянувши праксеологічний підхід як основу якості професійної підготовки державних службовців, а також проаналізувавши вітчизняну й зарубіжну літературу, чинне законодавство України та зарубіжних держав, ми дійшли висновку, що підвищення кваліфікації державних службовців - це широке й багатозначне поняття, яке можна розглядати як різновид професійної освіти, що спрямований на підготовку державних службовців. Підвищення кваліфікації державних службовців - це постійне удосконалення рівня професійних теоретичних знань і навичок, що дає їм змогу кваліфіковано та максимально ефективно виконувати свої повноваження.

\section{Jimepamypa}

1. Про державну службу : Закон України від 10.12 .2015 p. № 889-VIII / Верховна Рада України. URL: https://zakon.rada.gov.ua/laws/show/889-19 (дата звернення: 19.12.2019).

2. Про затвердження Положення про систему професійного навчання державних службовців, голів місцевих державних адміністрацій, їх перших заступників та заступників, посадових осіб місцевого самоврядування та депутатів місцевих рад : Постанова Кабінету Міністрів України від 06 лютого 2019 р. № 106 / Кабінет Мiністрів України. URL: http://zakon.rada.gov.ua/laws/ show $/ 106-2019-\%$ D0\% BF (дата звернення: 19.12.2019).

3. Біляковська О.0. Праксеологічний підхід як основа якості професійної підготовки майбутніх вчителів в Україні та Польщі. Портал наукових конференuiǔ. URL: https://www.cuspu.edu.ua (дата звернення: 19.12.2019).

4. Ведомости Верховного Совета Республики Беларусь. 1993. № 32. С. 416-470. URL: www.bns.gov.br (дата звернення: 19.12.2019).

5. Государственная служба и государственные служащие во Франции : Информационные и учебные материалы. Москва, 1996. 879 с.

6. Майборода В.К. Проблеми розвитку праксеологічних умінь майбутніх компетентних фахівців вищої школи України. Вища освіта України. 2018. № 4. С. 31-36.

7. Сацков Н.Я. Практический менеджмент. Методы и приемы деятельности руководителя. Донецк : Сталкер. 448 c.

8. Kotarbiński, T. Traktat o dobrej robocie. Wrocław : Ossolineum. $531 \mathrm{~s}$. 


\section{Анотація}

Корнута Л. М. Праксеологічний підхід як основа ефективного забезпечення підвищення кваліфікації державних службовців в Україні. - Стаття.

У статті розглянуто сутність праксеологічного підходу у професійній підготовці державних службовців в Україні із урахуванням досвіду окремих європейських країн. Визначено особливості праксеологічного підходу при застосуванні такого виду професійної освіти, як підвищення кваліфікації.

Зазначається, що у системі професійної підготовки державних службовців можна виокремити три складники - змістовий, технологічний і особистісний, у контексті дослідження яких необхідно акцентувати увагу на технологічному складнику як такому, що забезпечує реалізацію праксеологічного підходу. Саме праксеологічний підхід у контексті підготовки державного службовця являє собою найважливішу змістову характеристику професійної спрямованості особистості майбутнього професіонала.

Акцентовано, що головним завданням праксеологічного підходу у процесі підготовки державних службовців є вивчення й упровадження необхідних знань для здійснення ефективної діяльності. Зауважено, що саме ефективність виступає як показник якості професійної підготовки, а також як якісна категорія, що сприяє розвитку та вдосконаленню професійної діяльності державного службовця. Використання праксеології у сфері професійної підготовки державних службовців є основою для розуміння та дослідження професійної службової діяльності з позиції практичних цінностей, зокрема ефективності та результативності. Це важливо у процесі оцінювання результатів службової діяльності.

Визначено, що ефективність діяльності системи професійного навчання державних службовців може бути досягнута за умови відповідності професійної підготовки та післядипломної освіти вимогам освіти для суспільства, побудованого на знаннях і інформації. Цими вимогами $є$ такі: освіта протягом усього життя; освіта без кордонів, що Ірунтується на інформаційно-комп'ютерних технологіях і доповнює традиційні методи і технології новими можливостями; освіта за креативними моделями навчання та індивідуальними освітніми траєкторіями; освіта, що розвивається на основі фундаментальних знань. Одним із таких видів професійного навчання, що покликаний забезпечити високу освіченість та професійну компетентність державних службовців, є саме підвищення кваліфікації. Варто пам'ятати, що проблему підвищення кваліфікації державних службовців можна розглядати й у межах безперервної освіти. Праксеологічний підхід таке дозволяє. Так, більшість розвинених держав здійснює політику безперервного продовження освіти й підготовки кадрів.

Специфіка функціонування системи підвищення кваліфікації державних службовців у контексті праксеологічного підходу полягає в тому, що вона є підсистемою державної служби, обслуговує їі, готуючи високопрофесійні кадри. Це відбувається через вирішення низки таких завдань: приведення рівня професійних знань, умінь і навичок державних службовців у відповідність до вимог теорії та практики публічного управління; вивчення й застосування на практиці передового світового досвіду й досягнень науки державного будівництва та науки управління; формулювання установок на оволодіння предметом діяльності у сфері державної служби; формування професійних здібностей державних службовців.
Ключові слова: державний службовець, європейська інтеграція, професійний розвиток, праксеологічний підхід, професійне навчання, підвищення кваліфікації.

\section{Summary}

Kornuta L. M. A praxeological approach as a basis for effectively ensuring civil service training in Ukraine. Article.

The article deals with the essence of the praxeological approach in the professional training of civil servants in Ukraine, taking into account the experience of individual European countries. The peculiarities of the praxeological approach in the application of this type of vocational education as professional development are determined.

It is noted that in the system of training of civil servants can be distinguished three components - content, technological and personal, in the context of the study should focus on the technological component, such as to ensure the implementation of the praxeological approach. It is the praxeological component of the training of the civil servant that is the most important content characteristic of the professional orientation of the future professional's personality.

It is emphasized that the main task of the praxeological approach in the process of training civil servants is to study and implement the necessary knowledge to carry out effective activities. It is noted that efficiency is an indicator of the quality of vocational training, as well as a qualitative category that promotes the development and improvement of professional activity of public servants. The use of praxeology in the field of training of civil servants provides a basis for understanding and researching professional service activity in terms of practical values, in particular efficiency and effectiveness, which is important, in particular, in the process of evaluating performance.

It is determined that the effectiveness of the system of vocational training of civil servants can be achieved provided that vocational training and postgraduate education are in compliance with the requirements of a knowledge-based and information-based society, namely: lifelong learning; borderless education, based on information and computer technology, that complements traditional methods and technologies with new opportunities; education by creative learning models and individual educational trajectories; education that develops on the basis of fundamental knowledge. One of the types of vocational training that aims to provide high level of education and professional competence of civil servants is the advanced training. It is worth remembering that the problem of upgrading the skills of civil servants can be considered within the framework of continuing education. Actually, a praxiological approach allows this. Yes, most developed countries have a policy of continuing education and training.

The specificity of the functioning of the civil servants advanced training system in the practical approach is that it is a subsystem of the civil service and serves it by training highly professional personnel. This is done through a series of tasks: bringing the level of professional knowledge, skills and skills of civil servants in line with the requirements of public administration theory and practice; study and application in practice of the best world experience and achievements of the science of state building and science of management; formulation of installations for mastering the subject of activity in the sphere of public service; formation and development of professional abilities of civil servants.

Key words: civil servant, European integration, professional development, praxeological approach, vocational training, professional development. 